\title{
Applying SF-based Genre Approaches to English Writing Class
}

\author{
Yan $\mathrm{Wu} \&$ Hailin Dong \\ College of Foreign Languages, Hebei Polytechnic University \\ Tangshan 063009, China \\ Tel: 86-315-259-2193Ｅ-mail: strawberry_20082008@126.com
}

\begin{abstract}
By exploring genre approaches in systemic functional linguistics and examining the analytic tools that can be applied to the process of English learning and teaching, this paper seeks to find a way of applying genre approaches to English writing class.
\end{abstract}

Keywords: Systemic functional linguistics, Genre-based approach, Context of culture, Schematic structure, Context of situation, Field, Tenor, Mode

\section{Introduction}

Genre-based approach has been widely adopted in language teaching and researching. In referencing to Coffin (2001, pp. 108-113) and Hammond and Derewianka (2001, chap. 27), genre-based approach is discussed mainly from three perspectives: English for Specific Purposes (ESP), New Rhetoric studies and systemic functional linguistics. ESP mainly concerns with equipping the target group of language learners with the form of language in need (Swales, 1990a; A. Johns, 1991; Bhatia, 1993; Dudley-Evans and St John, 1998; cited in Hammond \& Derewianka, 2001, p. 186). New Rhetoric studies take a primary concern on the relations between text and context and it considers genre a way to accomplish social actions or purposes (Coffin, 2001, p. 111; Hammond \& Derewianka, 2001, pp.186-187). The study of Genre-based approach in this paper is discussed from a systemic functional perspective.

\section{Examining Genre-based Approach from a Systemic Functional Perspective}

\subsection{The outline of systemic functional linguistics}

Systemic functional linguistics is mainly aimed at solving problems confronted language users (Coffin, 2001, p. 94). It attempts to enable language users to learn and use language proficiently in social situations. Just as Coffin (2001) summarizes, systemic functional linguistics mainly focus on "the social and culture role of language" (p. 94). Compared with other linguistic schools, there are some distinguishing features of systemic functional linguistics. As mentioned by Martin (2001, p. 151), systemic functional linguistics holds a primary concern on the choices of language. In other words, language is considered as sets of choices from which speakers make choices to convey different meanings; Second, systemic functional linguistics focuses on the relation between language and context. Malinowski (as cited in Knapp \& Watkins, 1994, p. 4) used the terms 'the context of culture' to refer to 'beliefs', 'values' and 'attitudes' of language users; and used the term 'the context of situation' to refer to the 'immediate' language circumstances. Christine and Unsworth $(2000$, p. 2) noted three distinctive features of systemic functional linguistics. First, systemic functional linguistics concentrates on three major functions of language: 'ideational' or 'experiential' function applied to represent experience; 'interpersonal' function applied to maintain and build relationships between people; 'textual' function applied to combine the sentences and clauses into a cohesive text. Second, language is taken as sets of choices of meaning. Thirdly, systemic functional linguistics takes the study of the whole text as an object. Coffin (2001, pp. 94-96) mentioned that systemic functional linguistics approach deals with both the spoken and written language; sentences, clauses and text.

To sum up, systemic functional linguistics has provided a broad perspective on language. Language is served as resources consisting of potential meanings from which language users can make choices and turn out functional texts in terms of different contexts.

\subsection{What is Genre?}

In terms of the context genre embedded and the text types it produces, the term genre can be explored from three aspects. First, genre is a social process. It is a kind of social activity following some sequenced stages, in which language is used and composed into spoken or written texts. The form of the texts can be either formal or informal; either standard or non-standard, in terms of the contexts embedded. Second, genre-based possesses a certain purpose or goal. People use genre approach to achieve a goal or accomplish a purpose in social activities. For example, the genre used in a sales encounter is used to sell or buy something. Third, the schematic structure of genre is dynamic rather than statistic. Genre is a social activity; it differs in accordance with the social contexts, including the context of situation 
and the context of culture. It is changing horizontally as well as transversely. By horizontal change, it mean it is changing in conformity with values, beliefs, ideologies and habits of peoples from different cultural backgrounds. By transverse change, It means it is changing with the progressing of the times. For example, the development of technology usually leads to new genres; such as the invention of telephone make the verbal texts available on telephone. However, it does not mean that genre cannot be taught and the teaching of genre is unnecessary. As Knapp and Watkins (1994, p. 20) explained, genres are 'relatively' stable in social interaction and it is proved and shown that text types including report, exposition, explanation and debate are essential for school students learn and compose texts.

\section{SF-Based Genre Approach in Language Learning and Teaching}

SF-based genre approach has developed analytic tools to help language learning as well as language teaching. It examines the surface structure of a text by following the schematic structures of a text and also it can look into the inner structure of the text by analyzing the register variables (field, tenor and mode) of a text (Burns, 2001, p. 126).

Schematic structure (or generic structure) is valuable in working out the overall structure of a particular text. By learning the schematic structure of a text, students can become a good controller over different text types. Knapp and Watkins (1994, chap. 1) have developed a Teaching and Learning model based on SF-based genre approach. There are three stages in this teaching and learning process: Stage 1 aims to connect students' experiential knowledge with the language of writing. Stage 2 aims to expose the students to the generic structure of a particular text. Stage 3 aims to help the students with the grammar involved. In addition, Hammond (as cited in Burns, 2001, p. 202) has modeled a Teaching-learning circle to demonstrate how genre can be applied in teaching and learning process. There are also three stages to follow: Stage 1 involves modeling the generic structure of the model text. Stage 2 involves the joint efforts of a teacher and students to work out another text with the same genre. Stage 3 involves students' individual work and the teacher and learners editing (Burns, 2001, p. 202).

Another analytical tool in SF approach is based on the analysis of register variables. Knapp and Watkins (1994) defined, "register is a term for understanding how the variable elements of the context of situation (what/ field, who/tenor, how/mode) affect the form and meaning of a text" (p.12). Therefore, by valuing the context of situation through register analysis, we are able to get the particular functional genre in a particular culture. Chrisitie and Unsworth (2000, p. 13) drew a table that showed clearly the relationship between genre, register and language. It was illustrated that Genre is realized by combination of different values of the register variables. The register variables are realized by language. Language is the means by which we 'read' both register and genre (p. 13). The variables of register, field, tenor and mode, are defined by Butt, Fahey, Feez, Spinks and Yallop (2000) as follows:

Field: what is to be talked or written about, the long and short goals of the text;

Tenor: the relationship between the speaker and hearer (or, of course, writer and reader);

Mode: the kind of text that is being made. (p. 5)

These three variables of the context of situation are correspondent with the three metafunctions of language and will influence the form and meaning of the text. As Gerot (1995, p. 38) noted, field tenor and mode, respectively influences experiential meanings, interpersonal meanings and the textual meanings.

In addition to the context of situation, another aspect of the context-context of culture may also influence the form and meaning of a text. Gerot and Wignell (1994) explore it from three aspects: "being ('who we are'), doing ('what we do') [and] saying ('what we say')" (p. 10). For example, if you are a college teacher in china, the being of a Chinese teacher determines what you do and what you say. You are not expected to act as a foreign teacher. We hold the different values. You are respected by your students and most time you are a problem-solver and a knowledge-conveyer. While in western countries, a teacher can encourage the students to work out the problems on their own.

To draw a conclusion, SF-based genre approach has provided language teachers and language learners with an overall and a specific view to texts. It can work as a problem-solver to facilitate language learners to overcome the problems in learning. And it can work as a good assistant; teachers can use it to work out an effective teaching model.

\section{Applying a SF-Based Genre Approach to Teaching Practice}

\subsection{Outline of This Course}

This course is a common-core college English course. It is attempting to improve students' English skills, such as listening, speaking, reading and writing. Writing is a basic language skill required in language learning. This paper is aimed to explore genre-based approach in teaching narrative.

\subsection{Pre-lesson work}

Before the lesson, a research was conducted on the generic structure of a narrative. Based on the analysis of several narrative texts, in referencing to the book of Butt et al. (2000, p.11), the generic structure of a narrative is as follows:

Orientation: Tell the readers about who was involved and where it was happened? 
Complication: What was happened and the evaluation of the problem or crisis that contended in the

event?

Evaluation: What are the evaluations of the people involved in this event?

Resolution: How the problem or crisis was settled down and resumed to normal?

After that, an authentic text was selceted to serve as the model text in teaching. And the criterion for selecting is to see whether the text has a clear generic structure, the cohesion of the text, the language of the text and it should be of much interest.

\subsection{Teaching narrative writing in class}

The teaching was conducted through several stages: first, made the students clear about what is the function of writing a narrative. Second, lead the students to learn about the generic structure of a narrative and the lexico-grammar used in a narrative. Thirdly, asked the students to write about one of the unforgettable events happened in their life. This is not a straightforward task. Before they start to write their individual essay, they were asked to do several exercises to generate their ideas on what to write and how to organize the essay. Finally, the students composed their own essay. And after that, an assessment was carried out on their essays. Now the teaching is demonstrated into four steps.

Step 1: Model text:

Bicycle Adventure (C)

When I was a little girl, I rode my bicycle every afternoon. My bike was blue and shiny. I loved to ride it round my neighborhood after school. I spend an hour on it before going home every night. One day I met my sister, and we decided to ride to a new place. My sister was much more daring than I was. She was also stronger and more confident. We took our bikes to the hill in our neighborhood. My sister said she wanted to ride fast. I didn't think the hill was steep, so I agreed. I was excited to be going somewhere new. When we begin to ride, I discovered that the brakes on my bike didn't work. I squeezed and squeezed on the brakes, but the bike went faster, not slower. How did I know my brakes didn't work? I started to panic. My sister was laughing and shouting. She pretended that she was riding a horse. I crashed at the bottom of the hill. My bike hit a rock, and the front wheel turned. I fell to the ground. My leg got caught in the bike. My sister fell on the top of me. She was right behind me, yelling at her horse. My sister, her bike-horse, my bike, and I were in a pile at the bottom of the hill. I will never forget that day. I broke my leg, and my sister hurt her arm. When I got home from the hospital, my sister drew on my cast. She drew a horse that said "Sorry!" (Pike-Baky \& Blass, 2001, pp. 19-20)

Questions for students to think:

Q 1. Who were involved in the text?

Q 2. What was happened to them?

Q 3. What did the narrator think about their experience?

Q 4. How did the problem be solved?

By asking these four questions above, students are able to get access to the stages of writing a narrative. The stages incorporated the content of the text are as follows:

\begin{tabular}{|l|l|}
\hline $\begin{array}{l}\text { S1.Orientation: } \\
\text { who, where? }\end{array}$ & $\begin{array}{l}\text { "my sister" and "I" } \\
\text { "One day I met my sister, and we decided to ride to a } \\
\text { new place." }\end{array}$ \\
\hline $\begin{array}{l}\text { S2 Complication: } \\
\text { What was happened? } \\
\begin{array}{l}\text { What were the problems or crisis in the } \\
\text { event? }\end{array}\end{array}$ & $\begin{array}{l}\text { "We" rode in the hill. The brakes on "my" bike didn't } \\
\text { work. I was injured. }\end{array}$ \\
\hline S3. Evaluations & "I will never forget that day." \\
\hline S4. Resolutions & "I" was sent to the hospital. "My" sister apologized to \\
& "me". \\
\hline
\end{tabular}

Since the stages of composing a narrative can be changed, the teacher can draw the attention of the students to see the changes of stages and the effects of changing.

First, the teacher can ask a question:

Do you think all the narratives are following the same stages? Can we make some changes to the order of the stages?

The potential answers should be: 
No. Sometimes, there are some changes in the order.

Secondly, the teacher can convey to the students that how the sequence of stages can be changed, and what are the effects after changing.

We can organize an essay following the orders below:

Option 1: S3-S1-S2-S4

Option 2: S1-S2-S4-S3

Option 3: starting from stage 2

The first change may produce an attractive start. For example, you may start your essay like this: I still remember the first lecture in university which is a turning point in my life.

We can also change the order of stage 3 and stage 4 . You can show your evaluation at the end of the text. It might convey to the reader the implication of the text. For example, you may end your writing like this: Since then, I know that we should not too mean to forgive others.

We may come across the third order in a detective novel. The writer often lays the problem or crisis at the initial of the novel to raise the interest of readers. Since the structure of the novel is much more complex, and novel writing demands an innovative idea and sometimes it involves many genres.

Step 2 study of lexico-grammar:

In order to lead to students to have an insight of the lexico-grammar used in a narrative. The teacher can prepare some exercises for the students to practice. You can mainly focus on the time expressions, including time words, phrases and clauses; and the simple past tense. In doing the exercises, students may come across some problems about the usage of the time expressions and the regular and irregular changing of verbs. The teacher can collect their problems and conduct the teaching concentrating on their problems.

Step 3 essay writing and assessment.

In this stage, students are required to write an unforgettable event happened in their life.

First, I set a brainstorming exercise to generate their idea of what to write. Ask the students, what kind of events will impress you a lot and you will remember forever?

The potential answers are: something very funny, sad, meaningful, miserable, scared, romantic, etc. Students are expected to offer more.

Second, I asked the students to discuss with partner how to compose their essay around the topics: what is the event you want to put down in you essay? What were the problems or crisis involved in this event? What were the solutions to them? What do you think or feel after this experience. While they are discussing the teacher can serve as a facilitator to help them clarify their ideas.

Finally, I asked students to compose their own essay individually. The teacher assesses their essays after they finish writing. The assessment will be conducted around two points: the generate structure of their essays and the lexico-grammar used in their essays.

\section{Conclusion}

To draw a brief conclusion, SF-based genre approaches provide language learners as well as teachers an overall view on learning and teaching language. I am expecting the feedback from my genre-based teaching class, hoping that my teaching experience can contribute more to the development of this genre-based approach.

\section{References}

Burns, A. (2001). Genre-based approaches to writing and beginning adult ESL learners. In C. Candlin \& N. Merces (Eds.), English Language Teaching in its social context (200-207). London: Routeledge.

Butt, D. , Fahey, R. , Feez, S. , Spinks, S. \& Yallop, C. (2000). Using functional grammar-An explorer's guide. Sydney: National Center for English Language Teaching and Research Macquarie University.

Chritie, F. \& Unsworth, L. (2000). Developing socially responsible language research. In L. Unsworth (Ed.), Researching language in schools and communities-Functional perspective (pp.1-26). London: Cassell.

Coffin, C. (2001). Theoretical approaches to writing language-A TESOL perspective. In A. Burns \& C. Coffin (Eds.), Analysing English in a global context (pp. 93-122). London: Routledge.

Gerot, L. \& Wignell, P. (1994). Making sense of functional grammar. Gerd Stabler, AEE.

Gerot, L. (1995). Making sense of text. Gerd Stabler, AEE. 
Hammond, J. \& Derewianka, B. (2001). Genre. In R. Carter \& D. Nunan (Eds.). The Cambridge guide to teaching English to speakers of other languages (pp. 186-193). Cambridge: Cambridge University Press.

Knapp, P. \& Watkins, M. (1994). Context, text, grammar: Teaching the genres of grammar of social writing in infants and primary classrooms. Sydney: Text Productions.

Martin, J. R. (2001). Language, register and genre. In A. Burns \& C. Coffin (Eds.), Analysing English in a global context (PP. 149-166). London: Routledge.

Painter, C. (2001). Understanding genre and register: Implications for language teaching. In A. Burns \& C. Coffin, Analysing English in a global context (pp. 167-180). London: Routledge.

Pike-Baky, M. \& Blass, L. (2001). Tapestry-Writing 2. Beijing: Tsinghua University Press. 